\title{
Beban Masyarakat Adat Menghadapi Hukum Negara
}

\author{
M.Syamsudin \\ Fakultas Hukum Universitas Islam Indonesia Jogjakarta \\ e-mail : m.syamsudin@fh.uii.ac.id
}

\begin{abstract}
The most common type of conflict involving indigenous people is the dispute on the ownership of economic resources and cultural sites which are convicted and is guaranteed as traditional indigenous rights. In this regard, indigenous people stand vis a vis with investors' interest which is usually safeguarded by state legal instruments. Indigenous people are shaky in this kind of conflict, and in the factual cases, the process to weaken and destroy indigenous community has been made through regulations, policies as well as the real actions made by the government.
\end{abstract}

Keyword: Burden Of Indigenous People, The Ideology Of Legal Centralism, State Regulation

\section{Pendahuluan}

Sejak semula para pendiri negara (The Founding Fathers) Republik Indonesia menyadari bahwa bangsa Indonesia adalah bangsa yang majemuk (plural). Semboyan Bhinneka Tunggal Ika merupakan wujud penghormatan dan apresiasi filosofis bangsa Indonesia atas kemajemukan atau keanekaragaman yang dimilikinya. ${ }^{1}$ Keanekaragaman yang dimaksud dapat dilihat pada realitas yang ada dalam berbagai kelompok masyarakat adat, ${ }^{2}$ yang kini termasuk dalam bagian integral dari bangsa

${ }^{1}$ Pada tahun 1995, menurut Badan Pusat Statistik terdapat kurang lebih 100 Suku Bangsa, 300 Bahasa Daerah, 5 Agama Besar. Terdapat kurang lebih 900 buah pulau yang sudah dihuni dari sekitar 17.008 pulau di Indonesia yang ada. Baca Laki-laki dan Perempuan dalam Angka. Badan Pusat Statistik. 1995;

2 Pada tahun 1920 van Vollenhoven menemukan 19 lingkungan masyarakat adat dengan hukum adatnya masing-masing yang khas (adatrechtringen). Banyak sebutan yang diberikan pada masyarakat adat seperti: masyarakat terasing, suku terpencil, orang asli, peladang berpindah, masyarakat suku. Di negara lain digunakan 
Indonesia yang terdiri dari berbagai suku bangsa, kelompok penutur bahasa, penganut ajaran agama dan kepercayaan yang berbeda-beda. Keanekaragaman bangsa Indonesia ini akhirnya bermuara pada perbedaan adaptasi interaktif suatu komunitas terhadap lingkungan sekitarnya. Hal ini pada kenyataannya telah melahirkan komunitaskomunitas adat yang lebih memiliki kearifan lingkungan dan mode of production yang khas, berbeda satu dengan yang lain.

Menurut Kongres Masyarakat Adat Nusantara I (Maret 1999), masyarakat adat dirumuskan sebagai: kelompok masyarakat yang memiliki asal-usul leluhur (secara turun temurun) di wilayah geografis tertentu, serta memiliki sistem nilai, ideologi, ekonomi, politik, budaya, sosial dan wilayah sendiri. Ter Haar Bzn, dalam bukunya "Asas-asas dan Susunan Hukum Adat", menyatakan bahwa di seluruh kepulauan Indonesia pada tingkatan rakyat jelata, terdapat pergaulan hidup di dalam golongangolongan yang bertingkah laku sebagai kesatuan terhadap dunia luar, lahir dan batin. Golongan-golongan itu mempunyai tata susunan yang tetap dan kekal. Golongan-golongan manusia itu mempunyai harta benda, milik keduniawian dan milik gaib, yang bersifat persekutuan hukum. ${ }^{3}$

Soerjono Soekanto, menggambarkan masyarakat adat seperti desa di Jawa, marga di Sumatera Selatan, nagari di Minangkabau, kuria di Tapanuli, wanua di Sulawesi Selatan, Banjar di Bali, adalah kesatuankesatuan kemasyarakatan yang mempunyai kelengkapan-kelengkapan untuk sanggup berdiri sendiri, yaitu mempunyai kesatuan hukum, kesatuan penguasa dan kesatuan lingkungan hidup berdasarkan hak bersama atas tanah dan air bagi semua anggotanya. Penghidupan mereka berciri komunal dimana gotong-royong, tolong-menolong, serasa dan semalu mempunyai peranan yang besar. ${ }^{4}$

Jika dilihat ke belakang, keberadaan masyarakat adat ini telah ada jauh sebelum negara Indonesia lahir 17 Agustus 1945. Mereka hidup dengan penopang hukum adatnya masing-masing. Bentuk dan susunan masyarakat tersebut berbeda-beda antara yang satu dengan lainnya. Ada yang bernama desa di Jawa, Lembur di Sunda, Banjar di Bali, Nagari di

sebutan : first nation (AS dan Kanada); Indigenous cultural communities (Filipina); indigenous people (PBB).

${ }^{3}$ Ter Haar Bzn, Asas-Asas dan Susunan Hukum Adat. Jakarta: Pradnya Paramita, 1987, hlm. 30;

${ }^{4}$ Soerjono Soekanto dan Soleman b. Taneko, Hukum Adat Indonesia, Jakarta: PT Rajawali, 1983, hlm. 108; 
Minangkabau, Banua di Kalimantan, Nggolok di Rote, Kuan di Timor, Wanua di Sulawesi, Huria di Madailing, Huta di Batak, Dusun di Palembang, Gampong dan Meunasah di Aceh, dan sebagainya. Komunitas-komunitas tersebut telah ada, hidup dan melangsungkan aktifitas-aktifitas sosial kemasyarakatanmya di seluruh nusantara selama ratusan bahkan ribuan tahun. Dalam perjalanan waktu pola-pola interaksi sosial antar penduduk anggota komunitas adat dan pola interaksi dengan lingkungan fisiknya telah melembaga sedemikian rupa sehingga berujud suatu kesatuan sosial yang mandiri dan atau otonom, yang memliki pembagian kerja, sistem perangkat nilai dan aturan-aturan hukum sendiri. Komunitas-komunitas tersebut mandiri dalam arti mampu memenuhi berbagai kebutuhan fungsi politik, ekonomi, hukum serta fungsi mempertahankan kelangsungan keberadaan komunitas melalui sosialisasi nilai dan tradisi yang dilakukan dari generasi ke generasi.

Di dalam lingkungan masyarakat adat itulah bersemayam dan berlaku hukum adat. ${ }^{5}$ Hukum adat merupakan hukum yang lahir dari nilai-nilai budaya masyarakat adat sebagai cerminan dari sesuatu yang dianggap benar, patut dan baik dalam menata hubungan-hubungan mereka dengan lingkungan sosialnya maupun lingkungan alam fisiknya seperti tanah. Dalam menata hubungan sosial dan fisik telah melahirkan pranatapranata hukum adat seperti hukum kekerabatan (kinship), hukum perkawinan, hukum waris, hukum delik, hukum tanah dan sebagainya. Apa yang dianggap benar, patut dan baik itu terus berkembang sesuai dengan perkembangan sistem budaya masyarakat adat. Perkembangan tersebut bersifat evolusioner sesuai dengan konteks kebutuhan dan tuntutan masyarakatnya. Perkembangan tersebut berbeda-beda antara lingkungan masyarakat adat yang satu dengan lainnya. Menurut Seminar Hukum Adat di Jogjakarta Tahun 1975, Hukum Adat dirumuskan sebagai hukum asli masyarakat Indonesia yang tidak berbentuk perundangundangan yang mengandung unsur-unsur agama. ${ }^{6}$

Hukum adat berbeda dengan hukum positip dimana pembentuknya adalah negara dalam bentuk perundang-undangan. Hukum adat tidak dibentuk oleh negara akan tetapi lahir dari tradisi masyarakat sebagai pernyataan budayanya. Daya ikat keberlakuan hukum adat tidak seperti

${ }^{5}$ Masyarakat Internasional sering menyebut dengan istilah Indegenious Law, Pemerintah Belanda menyebut Adat Rrecht.

${ }^{6}$ Hilman Hadikusuma, Pengantar Ilmu Hukum Adat Indonesia, Bandung: Mandar Maju, 1994, hlm. 32. 
hukum positip yang dapat dipaksakan oleh aparat penegak hukum, termasuk polisi sebagai ujung tombak penegakannya. Kehadiran hukum adat tidak memikirkan dan mempertimbangkan apakah akan diakui atau tidak oleh kekuatan negara, melainkan karena harus muncul, berdasarkan kebutuhan masyarakatnya. Ini sebagai bukti otentitas hukum adat, karena hukum adat muncul dari dalam kandungan masyarakat sendiri secara otonom. Mengikuti pendapat Hart (1961), maka hukum adat lebih dekat dengan orde "primary rules of obligation" daripada hukum negara yang dibuat dengan sengaja (purposeful) dan karena itu lebih dekat dengan orde "secondary rules of obligation".

Hukum adat itu beranyaman dan berkelindan kuat dengan budaya setempat. Kata budaya di sini menunjukkan adanya unsur emosionaltradisional yang kuat dari hukum adat. Hukum adat juga merupakan hukum yang sarat dengan penjunjungan nilai-nilai tertentu. Bahkan di wilayah-wilayah tertentu di Indonesia, seperti Aceh dan Bali, bagi para pemeluknya, hukum adat adalah identik dengan hukum agama, maka dengan menerima dan menjalankan hukum adat mereka merasa beragama dan berbudaya.

\section{Berbagai Permasalahan yang Dihadapi Masyarakat Adat Dewasa Ini}

Meskipun keberadaan masyarakat adat diakui dan dilindungi berdasarkan konstitusi ${ }^{7}$ dan perundang-undangan yang ada, ${ }^{8}$ namun dalam kenyataan empirik akhir-akhir ini telah banyak bermunculan masalah-masalah yang dihadapi masyarakat adat di Indonesia. Masalahmasalah itu telah meyebabkan terjadinya berbagai sengketa yang menimpa masyarakat adat baik bersifat vertikal (struktural) maupun horizontal.

Sengketa vertikal/struktural adalah sengketa antara masyarakat adat yang menguasai sumber-sumber daya ekonomi seperti hutan, sungai, sumber bahan tambang, padang penggembalaan ternak, semak belukar, maupun tanah-tanah pertanian versus (melawan) negara Indonesia/ pemerintah Indonesia (baik sebagai pelaku/penjamin hak) dan atau kepentingan perusahaan / proyek-proyek bermodal besar. Sengketa yang

\footnotetext{
${ }^{7}$ Baca Pasal 18B UUD NKRI 1945.
}

${ }^{8}$ Banyak perundang-undangan yang mengakui keberadaan masyarakat adat beserta hak-hak tradisionalnya seperti UU Kehutanan, UU Agraria, UU Pemerintah daerah dan sebagainya. 
melibatkan masyarakat adat tersebut pada umumnya berupa sengketa mengenai penguasaan sumber-sumber ekonomi dan pangkalan budaya yang sehari-hari diyakini dan dijamin sebagai hak-hak adat mereka seperti : 1. Hutan-hutan perburuan yang terjadi pada orang-orang Amungme, Kamoro, Kerom, Asmat dan Tubelo; 2.Dusun-dusun sagu yang terjadi pada orang-orang Asmat, Kerom dan Ayawasi; 3. Hutan-hutan belukar bekas ladang yang terjadi pada orang-orang Dayak, Bunggu, Tubelo dan tangkul; 4. Padang-padang penggembalaan ternak terjadi pada orangorang Amanuban, Biboki, dan Sumba; 5. Kebun-kebun tanaman keras yang terjadi pada orang-orang Sumba, Amarasi, Nias, Dayak dan Galela; 6. Ladang-ladang tanaman semusim yang terjadi pada orang-orang Tobelo, Lauje dan Galela.

Pihak-pihak luar yang terlibat segketa tersebut meliputi: 1. Perusahaan-perusahaan pemegang Hak Guna Usaha (HGU) seperti terjadi di Arso, Palentuma, dan galela; 2. Perusahaan-perusahaan pemegang Hak Pengusahaan Hutan (HPH) Tanaman Industri yang terjadi di Gamlaha, Kupang Barat, Anakalan, Uma Talivaq, Bilu dan Lalobatan; 3. Perusahaanperusahaan pemegang Hak Pengusahaan Hutan $(\mathrm{HPH})$ yang terjadi di Sawa Erma, Demta, Timika, Bintuni, dan Halmahera Utara; 4. Perusahaanperusahaan pemegang Hak Kuasa Pertambangan (HKP) dan Hak Guna Bangunan (HGB) yang terjadi di Tembagapura, dan Kuala Kencana; 5. Dinas Perlindungan Hutan dan Pelestarian Alam yang terjadi di Manggarai Tengah; 6. Dinas Pekerjaan Umum yang terjadi di Kiritana; 7. Badan Pertanahan Nasional yang terjadi di Tinombo, Lampung dan Galela.

Dari sengketa tersebut dapat diketahui adanya fakta-fakta sebagai berikut: 1. Terdapat dua kepentingan yang berbeda atas satu objek yang sama, yaitu kepentingan masyarakat adat dan kepentingan negara/ pemerintah/pemodal; 2 . Terdapat dua sistem hukum yang berbeda yang digunakan oleh dua pihak yang bersengketa, yaitu hukum adat di satu sisi dan hukum positip (negara) di sisi lain; 3. Dalam kenyataan terjadi proses marjinalisasi posisi hukum adat oleh hukum negara, yaitu proses sistemik yang meminggirkan kedudukan hukum adat yang semula dianggap penting dan berharga bagi masyarakat adat dan menegasikannya menjadi hukum yang kosong dan tak berarti.

Sengketa horizontal adalah sengketa yang terjadi antara masyarakat adat dari persekutuan yang berbeda. Contoh sengketa horizontal : 1 . Sengketa Masyarakat Adat Amungme dengan Dani di Irian, 2. Sengketa Masyarakat Adat Dayak Bahau dengan Bentian di Kalimantan, 3. 
Sengketa masyarakat adat Meto dengan Tetun di Timor, 4. Sengketa ini juga terjadi antara masyarakat adat dengan masyarakat non adat di wilayah setempat seperti masyarakat adat setempat dengan kaum transmigran (Dayak dan Madura di Sampit Kalimantan) dan kaum pedagang yang menempati teritori-teritori adat atas izin negara.

\section{Mencari Akar Penyebab}

Masyarakat adat di Indonesia sebenarnya merupakan salah satu golongan masyarakat yang paling rentan. Kerentanan dimaksud adalah ketidaktahanan masyarakat adat mempertahankan kedaulatan, otonomi dan identitasnya. Kerentanan tersebut disebabkan oleh tekanan-tekanan eksternal maupun kelemahan-kelemahan internal.

Kerentanan masyarakat adat mempertahankan hak-haknya dapat dikelompokkan menjadi : 1 . Adanya upaya pelemahan dan penghancuran yuridis. Pelemahan dan penghancuran yuridis adalah tindakan penegasian dan peniadaan hak-hak masyarakat adat melalui pemberlakuan berbagai hukum nasional oleh negara dan penerapan berbagai kebijakan pembangunan oleh pemerintah. Bentuk-bentuknya meliputi : a). Pemberlakuan undang-undang dan kebijakan yang menghancurkan hakhak tanurial adat atas sumber-sumber agraria. Misalnya pasal-pasal dalam UU Pokok Agraria (N0 5/1960) yang mengatur hak ulayat, masyarakat adat dan hukum adat, telah "meninabobokan" banyak pihak termasuk masyarakat adat sendiri. Pada kenyataannya sengketa-sengketa agraria yang muncul membuktikan adanya kebohongan UUPA untuk memudahkan pengambilan sumber-sumber agraria oleh negara. Sebab pengakuan negara terhadap hak-hak tanurial adat digantungkan pada syarat harus sesuai dengan kepentingan nasional yang kabur pengertiannya sehingga setiap orang dan atau lembaga menafsirkan secara berbeda dan disesuaikan dengan kepentingan penafsir; b)Pemberlakuan undang-undang yang menghancurkan sistem dan bentuk kelembagaan masyarakat adat. Misalnya pada tahun 1979 pernah diberlakukan UU N0. 5 th 1979 tentang Pemerintahan Desa. Undangundang tersebut telah menyeragamkan pemerintahan terkecil dalam hierarkhi pemerintahan di Indonesia menjadi desa atau kelurahan. Akibatnya bentuk-bentuk persekutuan dan kelembagaan adat dilebur dan diseragamkan dengan cara pembentukan pemecahan dan penyatuan dan penghapusan desa. UU tersebut juga telah memusnahkan identitas 
masyarakat adat, sebab pembentukan, penyatuan dan penghapusan tersebut bertujuan untuk membentuk desa tangguh dan mampu melaksanakan tugas-tugas pemerintahan untuk pembangunan tanpa memperhatikan ikatan-ikatan agama, kesejarahan, dan geneologis masyarakat dan teritorinya. Dampak lain UU tersebut juga telah mengkooptasi kepala-kepala adat dengan pemberian peran-peran baru sebagai Kepala Desa, Ketua LMD, Ketua LKMD dan pelestarian sikap serta perilaku feodal karena kepala desa selalu berusaha menyenangkan atasannya dengan melakukan semua yang diintruksikan walaupun bertentangan dengan nilai, norma dan kepentingan masyarakat adat; c). Kebijakan-kebijakan pembangunan yang menegasikan hak-hak masyarakat adat pada berbagai sektor seperti : investasi modal, transmigrasi, pariwisata, dan sebagainya. Di bidang investasi modal misalnya adanya investasi modal perusahaan besar baik dalam dan luar negeri di berbagai bidang telah mengakibatkan ekspansi dan eksploitasi sumber-sumber agraria.

Otonomi dan identitas masyarakat adat dimusnahkan oleh penggusuran-penggusuran yang dilakukan demi pengembangan berbagai proyek pembangunan. Teritori-teritori yang telah dikuasai oleh pemilik modal dengan berbagai hak dari negara kadang dipaksa-kosongkan demi kelancaran usaha-usaha kaum pemilik modal tersebut. Pengosongan paksa/penggusuran tsb merupakan pemusnahan identitas masyarakat adat. Dampak lainnya adalah eksploitasi anggota masyarakat adat (terutama perempuan dan anak-anak) sebagai buruh murah. Di sisi lain juga tumbuhnya kawin kontrak/kawin musiman telah menyebabkan demoralisasi masyarakat adat. Program pembangunan transmigrasi juga membawa dampak pada penghakan sumber-sumber agraria suatu masyarakat adat oleh golongan masyarakat lain. Penghakan tsb juga telah memusnahkan hak-hak tanurial masyarakat adat setempat. Perbedaan daya adaptasi dan akses IPTEK telah melahirkan gap-gap sosial yang makin lebar. Gap-gap itu menyebabkan ketidakpuasan masyarakat adat dari persekutuan-persekutuan setempat sehingga memunculkan sengketa di berbagai tempat. Pariwisata juga tidak lepas dari eksploitasi budaya untuk kepentingan ekonomi negara. Seremoni adat, kearifan adat, dan keaslian masyarakat adat dieksploitasi dan dijual sebagai komoditi pariwisata. Bisnis wisata telah menghancurkan nilai-nilai hakiki dan religius adat, tradisi maupun budaya yang menyatu pada berbagai seremoni dan pengetahuan serta keahlian-keahlian asli. Pelemahan dan 
penghancuran praktis; 2. Pelemahan dan penghancuran praktis adalah tindakan-tindakan negatif terhadap masyarakat adat oleh aparat pemerintah, lembaga non pemerintah dan masyarakat non adat. Bentuknya dapat berupa tindakan represif dan stereotipe-stereotipe sosial politik. Tindakan represif adalah tindak-tindak kekerasan yang dilakukan seperti : penganiayaan, pembunuhan, dan teror-teror mental. Tindakan tersebut dilakukan untuk meredam aksi-aksi masyarakat adat mempertahankan hak-hak tanurialnya. Tindakan-tindakan tersebut dilakukan oleh oknum aparat pemerintah sipil dan militer. Dampaknya adalah trauma-trauma psikologis dan penurunan populasi masyarakat adat yang mengarah pada pemusnahan etnis. Stereotipe adalah cap-cap negatif yang diberikan pada masyarakat adat. Cap-cap tersebut diberikan oleh organisasi-organisasi pemerintah maupun aparat pemerintah dan masyarakat adat wilayah berbeda. Stereotipe ini melahirkan sikap-sikap dan perlakuan diskriminatif terhadap kepentingan sosial politik masyarakat adat. Cap-cap sebagai masyarakat terasing, primitif, kanibal, orang hutan, anggota PKI, anti Pancasila, anti pemerintah merupakan stereotipe sosial dan politik pada masyarakat adat; 3). Kelemahankelemahan internal. Kelemahan-kelemahan masyarakat adat terdiri dari : a). Kelonggaran ikatan kekerabatan, yang disebabkan oleh masuknya orang-orang luar ke dalam persekutuan melalui ikatan-ikatan perkawinan; b). komersialisasi sumber daya adat, yang disebabkan oleh perubahan ukuran ekonomi yang berimplikasi pada eksploitasi sumber-sumber agraria, ritus-ritus keagamaan, acara-acara adat dan budaya untuk menghasilkan uang. Eksploitasi-ekploitasi ini memicu konflik-konflik internal karena ada pihak yang tidak setuju; c). penyangkalan identitas, yaitu sikap generasi baru masyarakat adat yang telah mendapatkan pendidikan formal, pernah tinggal dan berinteraksi dengan masyarakat kota dan telah menganut salah satu agama samawi. Budaya dan tradisi disangkali dan berusaha dirombak tanpa memperhatikan nilai-nilai dasarnya. Ia menganggap bahwa budaya dan adat-istiadat tersebut sudah kuno, ketinggalan zaman, dan pemborosan; d). tumpang tindih peran, yaitu para fungsionaris adat juga berperan sebagai aparat desa, tokoh-tokoh agama, fungsionaris partai politik, maupun pengurus organisasi LSM. Ini mengakibatkan melemahnya peran utama sebagai fungsionaris adat. Akibat tarik-menarik peran tersebut, para fungsionaris adat tidak dapat bersikap memihak kepentingan masyarakat adat, ketika terjadi ancaman terhadap hak-hak masyarakat adat; e). peta-peta adat kognitif, yaitu peta-peta teritorial 
persekutuan adat yang hanya ada dalam kepala/ingatan anggota persekutuan masyarakat adat setempat. Peta-peta tersebut tidak tertuang/tergambar di atas fisik seperti kertas. Hal ini berakibat adanya peluang pihak lain untuk menganggap teritori adat sebagai wilayah yang kosong. Penafsiran tersebut telah menyebabkan negara, pemerintah, maupun kaum pemilik modal menghaki teritori-teritori adat.

\section{Pendekatan dan Strategi untuk Perlindungan terhadap Masyarakat Adat}

Belajar dari hikmah sejarah bangsa Indonesia dari rezim sebelumnya, angin reformasi telah menyadarkan kesalahan sikap negara (pemerintah) terhadap komunitas lokal (adat). Fakta bahwa Indonesia adalah negara yang sangat majemuk dari segala aspek (suku, ras, kelompok dan agama) membawa paradigma baru dalam cara berhukum dan bernegara yang semula sentralistik menuju ke desentralistik. Perubahan paradigma ini pertama-tama dapat dilihat dari politik hukum yang terdapat dalam Amandemen UUD 45 terhadap eksistensi masyarakat adat dan hak-hak tradisionalnya. Pasal 18B ayat (2) UUD menentukan : "Negara mengakui dan menghormati kesatuan-kesatuan masyarakat hukum adat beserta hakhak tradisionalnya sepanjang masih hidup dan sesuai dengan perkembangan masyarakat dan prinsip Negara Kesatuan RI yang diatur dalam undang-undang".

Rumusan UUD tersebut mensyaratkan 4 (empat) hal pengakuan dan penghormatan negara terhadap eksistensi masyarakat adat dan hak-hak tradisionalnya yaitu: sepanjang masih hidup; sesuai dengan perkembangan masyarakat; sesuai dengan prinsip NKRI; diatur dalam undang-undang.

Satjipto Rahardjo ${ }^{9}$ memberi catatan terhadap Pasal 18B UUD tersebut sebagai berikut. Pertama, Pasal 18B sudah menjadi hukum positip, sehingga setiap warga negara terikat kepadanya. Terikat berarti menerima dan harus dimulai dengan membaca isi peraturan tersebut. Membaca bukan sekedar mengeja kalimat demi kalimat, akan tetapi memberi makna terhadap peraturan tersebut. Makna yang diberikan haruslah bertolak dari tata pikiran (mind-set) bahwa hukum adat adalah suatu hukum yang khas mengandung bahan-bahan muatan sosio-antropologis Indonesia.

\footnotetext{
${ }^{9}$ Satjipto Rahardjo, Hukum Adat dalam Negara Kesatuan RI," Makalah Bahan Bacaan Program Doktor Ilmu Hukum Undip Semarang, 2006, hlm. 12
} 
Sifatnya yang penuh dengan afeksi membuat para penggunanya merasa bahagia. Hal ini menjadi alasan penting untuk menjaga dan merawatnya. Kedua, tata pikir (mind-set) yang demikian itu harus menjadi pemandu dalam mencermati dan memahami keempat syarat di atas. Keempat persyaratan tersebut dijabarkan oleh Rahardjo sebagaimana berikut ini.

Persyaratan sepanjang masih hidup perlu dimaknai bahwa persyaratan tersebut perlu diteliti dengan seksama dan hati-hati, tidak hanya menggunakan tolok ukur kuantitatif-rasional, melainkan lebih dengan empati dan partisipasi. Kita tidak semata-mata melakukan pengamatan dari luar, melainkan juga dari dalam, dengan menyelami perasaan masyarakat setempat. Metode yang digunakan adalah partisipatif.

Sesuai dengan perkembangan masyarakat harus ditafsirkan tidak dari segi ekonomi dan politik, melainkan dari kacamata masyarakat setempat. Penafsiran dari segi ekonomi politik mengandung risiko untuk memaksakan (imposing) kepentingan raksasa atas nama perkembangan masyarakat. Masyarakat adat perlu diberi peluang dan dibiarkan berproses sendiri secara bebas.

Sesuai dengan prinsip NKRI perlu dipahami dan dimaknai bahwa masyarakat adat (lokal) adalah satu kesatuan tubuh NKRI. Keduanya tidak perlu dihadapkan secara dikhotomis atau hitam putih. Masyarakat adat (lokal) adalah bagian dari darah-daging NKRI itu sendiri. Metode yang perlu dikembangkan adalah metode holistik untuk melihat masalah tersebut.

Diatur dalam undang-undang harus diberi catatan bahwa di negara hukum Indonesia, kehidupan sehari-hari tidak memadai segalanya diserahkan kepada undang-undang, karena akan menjadi tidak produktif. Banyak kejadian telah membuktikan tentang hal itu. Hukum (undangundang) yang selalu ingin mengatur ranahnya sendiri dan merasa cakap untuk itu telah gagal. Nonet \& Selznick (1978) menyarankan agar hukum itu dicerahkan dan diperkaya dengan Ilmu-Ilmu Sosial.

Penataan masyarakat adat (lokal) dengan undang-undang perlu memperhatikan kenyataan bahwa wilayah Indonesia yang dikenal sebagai negara kepulauan (archipelago) tidak mengalami perkembangan yang sama. Pada umumnya Jawa lebih bersifat masyarakat perkotaan dibanding dengan bagian besar wilayah di luar Jawa. Jawa telah terkena dampak yang kuat dari industrialisasi dan penetrasi modernitas. Perkembangan yang berbeda tersebut telah memunculkan dikhotomi antara daerahdaerah yang mengalami penetrasi industrialisasi dan daerah perawan. 
Mengikuti pandangan Unger ${ }^{10}$ (1971) bahwa hukum modern (positip) lebih mudah memasuki wilayah yang telah dijamah oleh industrialisasi dan menjadi perkotaan (urban) disebabkan perlawanan oleh hukum adat sudah sangat melemah. Kehadiran hukum modern (positip) membutuhkan keambrukan dari tatanan tradisional, seperti perkembangan modernitas yang terjadi di Eropa.

Dalam keadaan yang demikian diperlukan kehati-hatian yang luar biasa pada badan legislatif agar mampu menundukkan diri di atas konfigurasi masyarakat Indonesia seperti digambarkan di atas. Indonesia rasanya tidak bisa diatur dan dihukumi menurut kacamata "komunitas orang Senayan", sekalipun tentunya maksudnya baik. Tanpa pemahaman hukum yang bersifat anthropologis dan sosiologis, yakni perlunya mempertimbangkan adanya pluralisme hukum di masyarakat Indonesia, salah-salah akan menghasilkan malapetaka seperti yang pernah terjadi. Hukum (baca undang-undang) yang dibuat dengan mind-set modern tanpa mempedulikan dan mengantisipasi efeknya di tingkat lokal, bisa menghasilkan produk yang bersifat kriminogenik atau dalam istilah Rahardjo Legeslative Crime.

Oleh karena itu untuk melindungi komunitas adat/lokal, setidaktidaknya diperlukan langkah-langkah strategis dengan pendekatanpendekatan:1. Mengenali dan memahami masyarakat adat setempat. Pada langkah ini perlu dicari informasi-informasi yang terkait dengan : (a) mengenali budaya, adat istiadat, hukum, kebiasaan, agama dan kepercayaan. Dalam masyarakat adat terdapat berbagai kebiasaan, adatistiadat, hukum dan sebagainya, yang harus dihormati dan dihargai, meskipun mungkin pihak luar menganggap bahwa hal-hal itu salah. Pelanggaran terhadap kebiasaan/hukum tersebut akan melukai mereka meskipun mereka tidak menyuarakannya secara terbuka pada yang melanggar. Sekali mereka terluka, maka akan menganggap orang asing yang harus diwaspadai, sehingga mereka akan sulit diajak kerjasama; (b) mengenali lapisan-lapisan sosial dan konflik-konflik sosial yang mungkin ada. Pada umumnya terdapat 3 lapisan sosial dalam masyarakat adat, yakni orang asli, pendatang yang menetap karena ikatan perkawinan dan pendatang sementara seperti guru, pedagang, pegawai puskesmas dsb. Lapisan-lapisan tersebut mempunyai hak, kewajiban dan akses yang

${ }^{10}$ Roberto Mangabeira Unger, Teori-Teori Hukum Kritis, Posisi Hukum dalam Masyarakat Modern,2007, diterjemahkan oleh Dariyatno dan Derta Sri Widowatie. Dari Buku Law and Modern Society : Toward a Criticism of Social Theory, 1976 
berbeda terhadap sumber-sumber agraria, acara-acara adat, dan proses dalam pengambilan keputusan. Lapisan pertama selalu berpartisipasi aktif dan militan dalam proses penguatan dan pemberdayaan. Lapisan kedua cenderung hanya mendukung gerakan tanpa keterlibatan aktif. Lapisan ketiga merupakan pihak yang pasif karena pada umumnya tidak mempunyai kepentingan langsung; (c) mengenali pemimpin-pemimpin setempat. Dalam masyarakat adat biasanya terdapat 3 (tiga) jenis pemimpin dengan basis masing-masing yakni pemimpin berbasis adat (tokoh adat), pemimpin berbasis agama (tokoh-tokoh agama) dan pemimpin berbasis pendidikan formal (kepala sekolah dan guru). Ketiga tokoh tersebut mempunyai pengaruh yanmg kuat di dalam masyarakat adat, sehingga perlu diajak kerjasama; (d) mengenali kondisi geografis persekutuan adat setempat. Apakah masyarakat adat tersebut ada di tepi pantai, gunung, dataran rendah, dataran tinggi dan sebagainya; 2 . Tranformasi timbal balik. Langkah ini dilakukan untuk pertukaran ilmu, keahlian dan teknologi. Langkah-langkah yang dapat dilakukan seperti kegiatan pelatihan-pelatihan seperti : pendidikan hukum, pemetaan teritori adat, dan sebagainya; 3. Penggalangan dukungan. Langkah ini dilakukan untuk pengakuan dan penghormatan terhadap hak-hak masyarakat adat terhadap pihak lain di luar masyarakat adat.

\section{Penutup}

Meskipun keberadaan masyarakat adat sudah diakui dan dijamin perlindungannya berdasarkan konstitusi dan perundang-undangan yang ada, dalam kenyataan empirik banyak bermunculan berbagai permasalahan yang dihadapi masyarakat adat di Indonesia. Masalahmasalah tersebut telah menyebabkan terjadinya berbagai sengketa yang menimpa masyarakat adat terutama sengketa yang bersifat vertikal/ struktural. Konflik ini terjadi antara masyarakat adat berhadapan dengan negara atau hukum adat berhadapan dengan hukum positip. Konflik yang melibatkan masyarakat adat tersebut pada umumnya berupa sengketa mengenai penguasaan sumber-sumber ekonomi dan pangkalan budaya yang sehari-hari diyakini dan dijamin sebagai hak-hak tradisional masyarakat adat berhadapan dengan kepentingan-kepentingan investor melalui sarana hukum negara. Menghadapi konflik tersebut, masyarakat adat sangat rentan dan dalam praktek telah terjadi pelemahan dan penghancuran masyarakat adat baik melalui perundang-undangan, 
kebijakan dan tindakan praktis pemerintah. Oleh karena itu diperlukan strategi dan pendekatan yang tepat yang dapat melindungi keberadaan masyarakat adat beserta hak-hak tradisionalnya. Strategi dan pendekatan itu dapat meliputi: (a) mengenali dan memahami masyarakat adat setempat, dengan cara: (1) mengenali budaya, adat istiadat, hukum, kebiasaan, agama dan kepercayaan; (2) mengenali lapisan-lapisan sosial dan konflik-konflik sosial yang mungkin ada; (3) Mengenali pemimpinpemimpin setempat; (4) Mengenali kondisi geografis persekutuan adat setempat. Transformasi timbal balik. (b) Melakukan pertukaran ilmu, keahlian dan teknologi, yang dapat berupa kegiatan pelatihan-pelatihan seperti : pendidikan hukum, pemetaan teritori adat, dsb. (c) Melakukan penggalangan dukungan pihak luar untuk pengakuan dan penghormatan terhadap hak-hak masyarakat adat.

\section{Daftar Pustaka}

Edi Nasution. “Peranan Lembaga Adat dalam Mengurangi Konflik Horizontal dan Vertikal di Madailing Natal". Sumber : internet Hilman Hadikusuma, Pengantar Ilmu Hukum Adat Indonesia, Bandung: Mandar Maju, 1994.

Philippe Nonet dan Philip Selznick, Law and Society in Transtition: Toward Responsive Law, 1978. Diterjemahkan oleh Raisul Muttaqien, Cetakan

1. Bandung, Nusamedia, 2007.

Maria Rita Ruwiastuti Sesat Pikir Politik Hukum Agraria. Yogyakarta : Pustaka Pelajar, 2000.

Maria Rita Ruwiastuti, dkk., Penghancuran Hak-Hak Mayarakat Adat. Bandung : Konsursium Pembaruan Agraria (KPA) bekerjasama dengan INPI-Pact;

Roberto Mangabeira Unger, Teori-Teori Hukum Kritis, Posisi Hukum dalam Masyarakat Modern,2007, diterjemahkan oleh Dariyatno dan Derta Sri Widowatie. Dari Buku Law and Modern Society: Toward a Criticism of Social Theory, 1976.

Satjipto Rahardjo, "Hukum Adat dalam Negara Kesatuan RI," Makalah

Bahan Bacaan Program Doktor Ilmu Hukum Undip Semarang, 2006. Sandra Moniaga. "Hak-Hak Masyarakat adat dan masalah Serta Kelestarian Lingkungan hidup di Indonesia". Sumber Internet.

Soerjono Soekanto dan Soleman b. Taneko, Hukum Adat Indonesia. Jakarta:

PT Rajawali, 1983. 
Ter Haar Bzn, Asas-Asas dan Susunan Hukum Adat. Jakarta: Pradnya Paramita, 1987

Vollenhoven, C.Van, Orientasi dalam Hukum Adat Indonesia. Jakarta: Penerbit Djambatan, 1981.

Yones K. Pellokila dan Yando Zakaria, Doea Uma Batikar Samo. Bandung: KPA. 